\title{
EM DEFESA DA CIDADANIA: A DESOBEDIÊNCIA CIVIL COMO CAUSA SUPRALEGAL DE EXCLUSÃO DA CULPABILIDADE
}

\author{
Luan Guilherme Dias* \\ Zaiden Geraige Neto**
}

Em vez de serem apenas livres, esforcem-se para criar um estado de coisas que liberte a todos e também o amor à liberdade

Torne supérfluo!

(Bertolt Brecht)

SUMÁRIO: Introdução; 2 Desobediência civil: legitimidade bistórica e constitucional; 3 Características especiais da desobediência civil: aceitação voluntária das sanções e a (não) violência; 4 A respeito da culpabilidade na seara penal; 5 Desobediência civil como causa de exclusão da culpabilidade: a (In) exigibilidade de conduta diversa; 6 Conclusão; Referências.

RESUMO: O presente estudo tem por objetivo analisar a possibilidade de a desobediência civil, enquanto espécie do direito de resistência, atuar como causa de exclusão da culpabilidade na seara penal, em razão da inexigibilidade de conduta diversa por parte dos agentes desobedientes. Por meio do método dedutivo, a partir da análise de dados qualitativos, a pesquisa inicia investigando a teoria da desobediência civil, reconstruindo sua legitimidade histórica e constitucional, explorando também duas características que lhe são geralmente atribuídas: não violência e aceitação voluntária das sanções. Em seguida, analisam-se as nuances da culpabilidade na área criminal e a ação desobediente como uma dirimente supralegal, capaz de afastar a responsabilidade penal do agente desobediente. Conclui-se, ao final, que a desobediência civil pode ser considerada como causa de exclusão da culpabilidade, em determinados casos, pois não se pode exigir uma conduta diversa do agente desobediente que empenha esforços pela efetivação ou defesa de um direito, o que nada mais é que o exercício pleno da cidadania.

PALAVRAS-CHAVE: Desobediência civil; Cidadania; Exclusão da culpabilidade; Inexigibilidade de conduta diversa.

\footnotetext{
Mestrando em Direitos Coletivos e Cidadania pela Universidade de Ribeirão Preto (UNAERP), com bolsa pela Coordenação de Aperfeiçoamento de Pessoal de Nível Superior (CAPES), Brasil.

${ }^{* *}$ Doutor e Mestre em Direito pela PUC /SP. Professor de Direito do Mestrado Universidade de Ribeirão Preto/ SP - UNAERP. Professor convidado do curso presencial de pós-graduação Lato sensu em Direito Processual Civil da Faculdade de Direito da USP -Ribeirão Preto (FDRP/USP), Brasil. E-mail: zgneto@uol.com.br
} 


\title{
IN DEFENSE OF CITIZENSHIP: CIVIL DISOBEDIENCE AS A SUPRALEGAL CAUSE OF EXCLUSION OF CULPABILITY Y
}

\begin{abstract}
Current analysis discusses the possibility of whether civil disobedience, as the right to resist, may be the cause of exclusion of culpability in Penal Law due to the non-requirement of diverse behavior by disobedient agents. Employing the deductive method and through the analysis of qualitative data, current research investigates the theory of civil disobedience, its historical and constitutional legitimacy, underlining two characteristics: non-violence and the willful acceptance of punishment. Nuances of culpability in criminal law and disobedient acts are investigated as a supralegal impediment which is capable of shunning the penal responsibility of the disobedient agent. Civil disobedience may be a cause of exclusion of culpability in specific cases since one cannot demand a diverse behavior from the disobedient agent who makes all effort for the defense of a right. In fact, this is the full exercise of citizenship.
\end{abstract}

KEY WORDS: Civil disobedience; Citizenship; Exclusion of culpability; Nonrequirement of different behavior.

\section{EN DEFENSA DE LA CIUDADANÍA: LA DESOBEDIENCIA CIVIL COMO CAUSA SUPRA-LEGAL DE EXCLUSIÓN DE LA CULPABILIDAD}

RESUMEN: El presente estudio tiene por objetivo analizar la posibilidad de la desobediencia civil, como especie del derecho de resistencia, actuar como causa de exclusión de la culpabilidad en el campo penal, en razón de la inexigibilidad de conducta diversa por parte de los agentes desobedientes. Por intermedio del método deductivo, a partir del análisis de datos cualitativos, el estudio empieza investigando la teoría de la desobediencia civil, reconstruyendo su legitimidad histórica y constitucional, explorando también dos características que le son generalmente atribuidas: no violencia y aceptación voluntaria de las sanciones. Después se analiza los matices de la culpabilidad en el área criminal y la acción desobediente como una dirimente supra legal, capaz de alejar la responsabilidad penal del agente desobediente. Se concluye, al final, que la desobediencia civil puede ser considerada como causa de exclusión de la culpabilidad, en determinados casos, pues no se puede exigir una conducta diversa del agente desobediente que empeña esfuerzos por la concreción o defensa de un derecho, lo que nada más es que el ejercicio pleno de la ciudadanía.

PALABRAS CLAVE: Desobediencia civil; Ciudadanía; Exclusión de la culpabilidad; Inexigibilidad de conducta diversa. 


\section{INTRODUÇÃO}

O descompasso entre as pretensões mais básicas dos cidadãos brasileiros e as decisões adotadas pelos representantes políticos resultam em uma realidade caótica e desesperançosa, gerando uma infindável crise de desconfiança em nossas instituições. Atribuir ao cidadão o papel de destaque no cenário político e libertá-lo das diversas amarras sociais e políticas opressoras torna-se medida de urgência na atual configuração do Estado brasileiro.

Em meio a esse conturbado contexto, a desobediência civil apresenta-se como o meio capaz de inserir o cidadão no centro do debate político, ampliando os canais de diálogo na sociedade. Engrandecendo o binômio "liberdade-participação", característica essencial da atual concepção de cidadania, a ação desobediente desafia a lógica excludente do cenário jurídico-político, conforme destaca Repolês: "é por meio de ações de desobediência civil que a sociedade civil pode provocar de forma mais radical o sistema político e questionar a legitimidade das decisões que são tomadas em seu centro". ${ }^{33}$

No entanto, observa-se um cenário em que a repressão por parte do Estado cresce a cada dia. Manifestar-se pela nas ruas pela revogação ou alteração de uma política pública tem sido uma tarefa extremamente árdua, ainda que nenhuma norma seja desobedecida. Alicerçar a legitimidade da desobediência civil significa alargar o campo de atuação do cidadão na vida pública, permitindo também a contenção do jus puniendi estatal contra manifestantes políticos.

A teoria acerca da desobediência civil pouco desenvolveu a possibilidade de integração da prática contestadora com a área criminal, com o escopo de afastar a responsabilidade penal dos desobedientes civis. É escassa a literatura sobre o tema e pouco explorada a possibilidade de a desobediência civil atuar como causa de exclusão da culpabilidade, em razão da inexigibilidade de conduta diversa.

Assim, além de contribuir com o debate no cenário político-jurídico brasileiro, a pesquisa supre uma carência enorme no campo teórico. A partir do método dedutivo, com a análise de dados qualitativos, objetiva-se apresentar a desobediência civil como causa supralegal de exclusão da culpabilidade, com o escopo de afastar a responsabilidade penal do agente contestador, a fim de integrar a ação desobediente e a seara criminal.

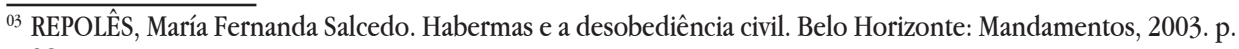
38. 
Para tanto, inicia-se com a teoria da desobediência civil, demonstrando a sua legitimação histórica, trazendo à luz a luta de Rosa Parks, e a sua legitimação jurídico-constitucional, a partir da teoria jurídica de Maria Garcia e outros pensadores nacionais e estrangeiros. Logo após, discute-se a limitação de duas características geralmente atribuídas à desobediência civil: não violência e aceitação voluntária das sanções.

Analisa-se, em seguida, a teoria da culpabilidade, dissecando suas principais características e contribuições para o sistema criminal moderno, a fim de extrair a devida compreensão sobre a exigibilidade de conduta diversa, predicado que pode excluir a responsabilidade criminal dos agentes contestadores. Feito isso, investigase a possibilidade da desobediência civil atuar como causa supralegal de exclusão da culpabilidade, possibilitando o diálogo e a integração da ação desobediente ao direito penal.

\section{DESOBEDIÊNCIA CIVIL: LEGITIMIDADE HISTÓRICA E CONSTITUCIONAL}

A história demonstra que o caminho trilhado pela humanidade sempre esteve ligado à resistência a opressão. O exercício do contrapoder político, denominado direito de resistência (iusresistentiae), constituiu-se, desde os primórdios, como verdadeiro mecanismo de autodefesa para os povos, legitimando as mais variadas formas de insurgência contra atos tirânicos de autoridades estabelecidas que atentassem contra a vida ou desrespeitassem os valores morais básicos de determinado grupo.

Pelos séculos, a doutrina da resistência à opressão progrediu e colaborou com a instituição do Estado moderno. Nesse sentido, a teoria contratualista de Thomas Hobbes e John Locke, cada um a sua maneira, merece destaque em razão de conceberem o direito de resistência como um direito inalienável, a disposição do cidadão sempre que o Estado atentar contra a segurança ou a vida do cidadão. ${ }^{0405}$

A declaração francesa dos Direitos do Homem e do Cidadão, documento histórico de 1789 que marca a chegada ao poder da classe burguesa, previa em

\footnotetext{
${ }^{04}$ HOBBES, Thomas. Leviatã: ou matéria, forma e poder de uma república eclesiástica e civil. São Paulo, Mandamentos, 2003. p. 115.

${ }^{05}$ RIBEIRO, Fernando Armando. Conflitos no Estado Democrático: por uma compreensão jurídica da desobediência civil. Belo Horizonte: Mandamentos, 2004. p. 88-94.
} 
seu artigo $2^{\circ}$ de forma incisiva que: "A finalidade de toda associação política é a preservação dos direitos naturais e imprescritiveis do homem. Esses direitos são a liberdade, a prosperidade, a segurança e a resistência à opressão". ${ }^{06}$

A legitimidade da ação resistente no Estado democrático de Direito, tal qual concebemos hoje, por sua vez, ressoa quando atua em favor da proteção da liberdade, dos ideais de democracia e em favor de transformações na estrutura social. O direito de resistência apresenta-se, então, como direito garantidor de outros direitos, despertando a ideia de reciprocidade entre cidadãos e governantes na esfera pública.

Vale ressaltar que o direito de resistência manifesta-se, em certas ocasiões, pela recusa à obediência e pela oposição ativa às normas jurídicas injustas ou opressivas - ainda que em âmbito exclusivamente pessoal. A legitimidade do direito de resistência torna-se manifesta em virtude de serem invocados os ideais de justiça que fundamentam a própria ordem jurídico-política.

Como anteriormente ressaltado, as lutas travadas pelos povos durante $o$ processo de desenvolvimento da sociedade sempre repercutiram no direito e, em diversas oportunidades, chegaram até a provocar o destino do direito. Compreendese, portanto, que a evolução da própria concepção de direito realiza-se por disputas, rupturas e conflitos internos e do constante processo de amadurecimento a partir da violação da norma jurídica. No cenário político brasileiro, marcado pela exclusão da população do centro decisório, a desobediência civil é imprescindível, pois permite que o cidadão atue de maneira decisiva, liberto das amarras sociais.

$\mathrm{O}$ dever de obediência à norma, ainda que inegavelmente necessário para o bom funcionamento da sociedade, mostra-se desarrazoado quando imposto de maneira incondicional. Ademais, é bom lembrar que a lei, para exigir a obediência dos cidadãos, deve estar de acordo com os princípios esculpidos na Constituição da República, respeitar direitos e garantias fundamentais e deve expressar a face da Justiça, para que o cidadão não seja compelido a desobedecer à norma.

Compreendendo tais pressupostos, podemos encarar a desobediência civil com mais maturidade e compreendê-la como o mecanismo capaz de gerar o imprescindível debate na esfera pública sobre os limites da lei e os deveres dos cidadãos e, do mesmo modo, capaz de ampliar os canais de diálogo na sociedade, devendo ser utilizada como última defesa das prerrogativas da cidadania ou em respeito aos direitos fundamentais.

${ }^{06}$ DECLARAÇÃO DOS DIREITOS DO HOMEM E DO CIDADÃO DE 1789. Disponível em: < http://www.fafich. ufmg.br/hist_discip_grad/DeclaraDireitos.pdf>. Acesso em: 22 jun. 2016. 
O precursor e responsável por insculpir o termo "desobediência civil" na teoria política moderna é Henry David Thoreau, que conclamava a desobediência contra a opressão. Em razão de não concordar com a política de escravidão e com o intuito de não financiar a desumana guerra de conquista travada pelos Estados Unidos da América contra o México, em um dos mais célebres atos de resistência da história moderna, recusou-se a pagar os impostos cobrados, sendo jogado na prisão em represália. Como consequência desse episódio, escreveu a célebre obra "Civil Desobedience", datada de 1849, em que questiona: "Deve o cidadão, sequer por um momento, ou minimamente, renunciar à sua consciência em favor do legislador? Então por que todo homem tem uma consciência?". ${ }^{07}$

Apresentando-se como uma espécie do direito de resistência ${ }^{08}$, no entanto, a desobediência civil enfrenta os mesmos problemas das outras formas de resistência: descrédito e desconfiança. É olhando para a história, não obstante, que podemos visualizar a contribuição da desobediência civil para o amadurecimento da sociedade e o aperfeiçoamento da democracia, eliminando qualquer desconfiança sobre o tema. O olhar ao passado revela a destemida história da costureira estadunidense negra, Rosa Louise McCauley (1913 - 2005), também conhecida como "Rosa Parks", um dos mais emblemáticos casos de desobediência civil na história.

Ante um cenário de intensa segregação imposto pelas leis racistas da cidade de Montgomery, no Estado do Alabama, nos Estados Unidos da América, Rosa Parks ousou resistir à opressão e deliberadamente desobedeceu à lei que segregava negros e brancos no transporte público. A opressão e a segregação racial estavam insculpidas na lei, compunham o sistema normativo, era "Direito".

O dia $1^{\circ}$ de dezembro de 1955 , nesse contexto, ficará marcado na história como o dia em que uma costureira pobre, após uma longa jornada de trabalho, decidiu desobedecer à lei que atribuía aos negros o dever de ceder o lugar nos ônibus aos brancos. Sua destemida ação gerou um grande movimento de boicote ao transporte público municipal, durante o qual a população negra teve de enfrentar a turba odiosa e a severa repressão policial. ${ }^{09}$

Em decorrência da corajosa atitude de Rosa, que chegou a ser encarcerada pela sua intrépida ação, o debate sobre os direitos civis dos negros ganhou imenso

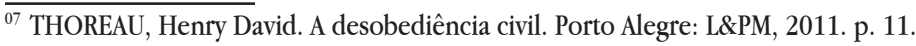

${ }^{08}$ BUZANELLO, José Carlos. Direito de Resistência Constitucional.2. ed. Rio de Janeiro: Lumem Juris, 2006. p. 147-180.

${ }^{09}$ RIBEIRO, Fernando Armando. op. cit. p. 365. 
destaque na sociedade norte-americana, com destaque para a figura de Martin Luther King. No ano seguinte à ação desobediente de Parks, a Suprema Corte dos Estados Unidos decidiu que a lei segregacionista de Montgomery era inconstitucional.

Verifica-se, de tal modo, que a desobediência civil desempenha o importante papel de garantir o respeito às minorias e permite que o cidadão seja ouvido perante as esferas do círculo oficial de poder da sociedade, aumentando a possibilidade do próprio aperfeiçoamento da comunidade política. Outorgando o papel de destaque ao cidadão dentro do cenário político, a desobediência civil tem o condão de realizar a necessária persuasão da opinião pública de que uma lei ou política pública é ilegítima e/ou injusta e que uma mudança é necessária e, sobretudo, urgente.

Apoiando-se no princípio constitucional da cidadania, a desobediência civil tem a capacidade de garantir a tão necessária liberdade de participação na vida pública, assegurando o aperfeiçoamento da sociedade por meio da rejeição daquelas normas exaradas do poder público que ofendam a direitos e garantias fundamentais. Nesse sentido, como bem ressaltou Lehfeld,

Exercer a cidadania é não estar submetido a amarras quando da participação no processo político; não encontrar óbices quando a Autoridade Púbica exigir a efetiva distribuição da justiça social. $\mathrm{Na}$ verdade, a liberdade é o principal motivo pelo qual os homens se encontram politicamente organizados. Uma vez tolhido esse campo de liberdade por um ato arbitrário, de cunho administrativo ou normativo, é facultada ao cidadão a resistência, no intuito de restabelecer os limites constitucionalmente previstos ao Poder Público. ${ }^{10}$

A interpretação sistemática da Carta Política brasileira, por outro lado, revela ser possível o cidadão desobedecer, em última instância, leis ou atos normativos que firam outros direitos fundamentais, em decorrência da soberania popular e da cidadania, pilares do regime democrático. O filósofo do liberalismo John Rawls afirma que pela desobediência civil invoca-se "a concepção da justiça comumente partilhada que subjaz à ordem política". ${ }^{11}$

Além da legitimidade bistórica que acompanha a prática desobediente, a desobediência civil também possui legitimação pela Constituição da República, em decorrência de sua cláusula de abertura material, contida no art. $5^{\circ}, \S 2^{\circ}$, que

\footnotetext{
${ }^{10}$ LEHFELD, Lucas de Souza. Modalidades de Participação-Cidadã no Horizonte de Concreção do Direito. In. FERREIRA, Luiz Alexandre Cruz (Org.). Hermenêutica, Cidadania e Direito. Campinas: Millennium, 2005. p. 162.

${ }^{11}$ RAWLS, John. Uma teoria da justiça. Lisboa: Fundamentos, 1993. p. 283.
} 
recepciona outros direitos não expressos no texto constitucional. A defesa de direitos e princípios constitucionais confere legitimidade à pràtica desobediente. Conforme preleciona a professora Maria Garcia,

A desobediência civil é um direito fundamental de garantia, contido no mandamento do art. $5^{\circ}, \S 2^{\circ}$, da CF. Decorre do direito constitucional à liberdade e destina-se, portanto, à proteção da cidadania, ápice da liberdade.

Como direito de garantia ou proteção pode consistir na resistência passiva ou exteriorizar-se em atos ou medidas, não jurisdicionais perante os Poderes Públicos, e tem como fundamentos o princípio democrático e o princípio republicano - do governo da res publica, com o seu requisito de igualdade e de participação nas esferas essenciais do Estado.

$[\ldots]$

Nesse sentido, o poder de intervir na produção da norma admite o poder de intervir na sua alteração ou modificação com fundamento, então, na sua incompatibilidade com a própria Constituição; daí a abrangência dos atos de autoridade igualmente conflitivos com a ordem constitucional, nesta compreendidos outros direitos fundamentais compatíveis. ${ }^{12}$ (Grifos da autora)

Assim, sem o prejuízo de outras garantias de participação de natureza administrativa e contenciosa, o cidadão, descontente com os caminhos trilhados pela administração pública, tem o direito-dever de vindicar, pela desobediência civil, mudanças no ordenamento jurídico ou fim de uma política injusta, opressora.

Dentro desta ótica, cumpre ressaltar que o ordenamento jurídico não pode ser entendido como a mera exaltação do status quo, neutro, desumano, imutável, inflexível, insensível e alheio aos anseios da população. Aliás, Habermas alerta que: "o Estado democrático de Direito não se apresenta como configuração pronta, e sim, como um empreendimento arriscado, delicado e especialmente falível e carente de revisão" ${ }^{13}$

A constante ineficácia dos mecanismos legais de prevenção de injustiças - lembrando que o nosso sistema político sequer conta com o recall, mecanismo capaz de permitir que a sociedade convoque uma consulta popular a fim de revogar ou não o mandato do parlamentar eleito - é o que acende o sinal de alerta e reafirma a necessidade de novas alternativas políticas de interferência no círculo oficial de

${ }^{12}$ GARCIA, Maria Desobediência Civil: direito Fundamental. 2. ed. São Paulo: Revista dos Tribunais, 2004. p. 296-297.

${ }^{13}$ HABERMAS, Jürgen. Jürgen. Direito e democracia: entre facticidade e validade. Rio de Janeiro: Tempo Brasileiro, 1997. v.1, p. 118. 
poder, como a desobediência civil.

A desobediência civil intenta construir uma democracia pujante, capaz de garantir a participação de todos no processo político decisório. Pela ótica social, a desobediência civil, além de dar voz aos amordaçados, afigura-se como uma conveniente forma de pressão e protesto ao poder público, quando este apresenta leis injustas ou pratica atos arbitrários, descuidando-se dos ideais esculpidos na Constituição Federal, que devem nortear a atuação estatal. Por fim, insta trazer à baila as palavras de Nelson Nery Costa.

A desobediência civil é, assim, o instrumento que permite ao indivíduo e à sociedade interferirem diretamente nas instituições públicas. Ainda que seja motivada por um comportamento político, repercute profundamente no sistema jurídico, transformando-o em mediador entre o Estado e os setores privados. Faz parte da própria essência da vida social do homem e representa o estuário de seus anseios e ideais, numa evidência de que o direito não é estático, mas dinâmico e seletivo, em constante procura da democracia e da justiça. ${ }^{14}$

\section{CARACTERÍSTICAS ESPECIAIS DA DESOBEDIÊNCIA CIVIL: ACEITAÇÃO VOLUNTÁRIA DAS SANÇÕES E A (NÃO) VIOLÊNCIA}

Alcançar o consenso a respeito de um assunto tão polêmico e que divide opiniões como é a desobediência civil não é uma tarefa simples. A multiplicidade de entendimentos sobre o tema abre um leque variado de possibilidades, o que pode ser aferido quando a pauta de discussão são as suas características e peculiaridades.

Para a maioria dos teóricos contemporâneos, a desobediência civil possui uma característica essencial: a ação deve ser guiada pelo princípio da não violência. A pacificidade do ato desobediente é uma característica bastante difundida e seria responsável por demonstrar aos demais cidadãos que os desobedientes civis não representam um "perigo ao bom funcionamento da sociedade".

A característica da não violência pretende expor a prática injusta perpetrada pelo opressor, buscando deslegitimar a própria ação estatal. Assim, com o objetivo de permanecer dentro dos marcos da civilidade, a desobediência civil não faria uso da violência para não perder justamente o seu elemento civil. Nesse sentido, Hannah Arendt aduz que a não violência seria a característica específica que garantiria a

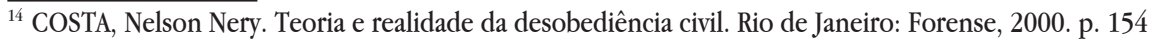


persuasão dos demais membros da sociedade e distinguiria os desobedientes civis dos rebeldes. ${ }^{15}$

Norberto Bobbio, de igual modo, afirma que a característica da não violência seria a responsável por diferenciar a desobediência civil de outras formas de contestação, tais como o motim, a rebelião, a revolução ou guerrilha. ${ }^{16}$ Conforme se verifica, parte dos comentadores da desobediência civil analisa a violência a partir de um conceito específico, identificando-a como toda ação que faça uso da força.

Esse discurso construído, de que a desobediência civil não pode ter nenhum vínculo com a violência, pode representar, em muitos casos, a inoperância da ação contestadora. Em algumas ocasiões, os desobedientes civis necessitam demonstrar força ante o aparelho estatal, seja rompendo obstáculos, obstruindo vias ou destruindo bens insignificantes, para pressionar o poder público, cobrando a alteração da situação que desencadeou o protesto.

Embora seja certo afirmar que a não violência reforça a legitimidade do ato contestador, deve-se levar em conta, na análise do caso concreto, os variados graus de violência e a sua manifestação na vida da sociedade a partir de um processo apurado de ponderação. A violência, caso manifeste-se em atos de desobediência civil, deve ocorrer apenas como incidente nunca como a razão de ser do ato contestador.

Dentro desta ótica, o eminente pensador norte-americano, John Rawls, afirma que "efetuar atos de violência suscetíveis de ferir e causar mal é incompatível com a desobediência civil enquanto forma de apelo", mas pondera que: "pode acontecer que, se este apelo não for sucedido, se recorra posteriormente à resistência pela força”. ${ }^{17}$

Avançando dentro desta mesma perspectiva, Nelson Nery Costa entende que

A utilização da força não deve, de modo algum, ameaçar às pessoas, principalmente a terceiros não envolvidos, porque ao se atentar contra as liberdades dos outros, perde-se a legitimidade do caráter civil. A violência pode dirigir-se apenas contra as propriedades, como ocupações forçadas de terrenos ou fábricas, quando for imprescindível para o êxito da campanha. A desobediência civil possui uma índole pacífica, mas está facultada a tática de empregar a força, quando esta significar o fortalecimento dos meios de expressão democráticos. ${ }^{18}$

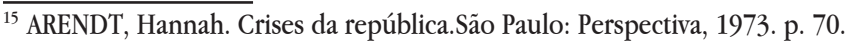

${ }^{16}$ BOBBIO, Norberto; MATTEUCCI, Nicola; PASQUINO, Gianfranco. Dicionário de política. 10. ed. Brasília: UNB, 1997. v1. P. 337

${ }^{17}$ RAWLS, John. op. cit. p. 284.

${ }^{18}$ COSTA, Nelson Nery. op. cit. p. 57
} 
A partir das perspectivas acima elencadas, entendemos que não se pode desprezar o caráter inovador que a violência carrega em sua manifestação, sobretudo quando se tratar de uma reação à violência iniciada pelo aparelho repressivo do Estado, em casos específicos, mesmo não sendo a alternativa mais indicada.

A legitimidade da desobediência civil é um dos seus pontos nevrálgicos e que a todo custo deve ser resguardada, de modo que a violência, caso seja utilizada como último recurso e não viole direitos humanos, deve ser reconhecida, uma vez que, conforme preceitua Felipe Prando: "o uso da força não pode ser desconsiderado, o que deve ocorrer é a prevalência até o limite possível da não violência". ${ }^{19}$

Assim, dependerá do caso concreto a análise a respeito da justeza de atos que façam uso de algum tipo de violência - desde que não violadora de direitos que resguardem a vida ou a dignidade humana - como sendo casos legítimos de desobediência civil.

Por outro lado, outra característica geralmente atribuída à desobediência civil e que causa enormes debates na doutrina é a aceitação voluntária das sanções por parte dos desobedientes civis.

Segundo alguns pensadores, essa característica também demonstraria a fidelidade do desobediente civil ao ordenamento jurídico. Influenciada pelas posturas de Thoreau, Mahatma Gandhi e Luther King, que aceitaram de bom grado submeterem-se ao cárcere, essa característica seria a responsável por demonstrar a franqueza e a boa-fé dos desobedientes civis aos demais membros da sociedade política.

Não se pode negar, evidentemente, que essa postura tem caráter simbólico muito grande e é capaz de influenciar os demais cidadãos a perceberem que determinados indivíduos estão dispostos até mesmo a sacrificarem-se, suportando os tormentos da prisão, para extirpar uma política de Estado injusta.

No entanto, essa posição apresenta-se como idealista e exige do desobediente civil um preço muito alto a ser pago para poder participar da vida política do Estado, resistindo contra eventuais abusos. Ora, se afirmamos que a desobediência civil é o mecanismo à disposição dos cidadãos para extirpar uma prática de Estado injusta, não podemos cobrar do ator desobediente que se sujeite ao cárcere por desrespeitar uma lei injusta.

\footnotetext{
${ }_{19}$ PRANDO, Felipe Cardoso. Desobediência civil: uma possibilidade para a realização dos Direitos Humanos. Ago. 2012. 130 p. Dissertação (Mestrado em Direito). Universidade Federal de Santa Catarina. Florianópolis, 2012. Disponível em: < https://repositorio.ufsc.br/handle/123456789/83869>. Acesso em: 05 jun. 2015. p. 85.
} 
A insistência de alguns autores em afirmar que o desobediente civil deve sujeitar-se de bom grado às sanções impostas pelo Estado demonstra-se simplista, ao não considerar os trágicos efeitos do cárcere sobre a psiquê humana, sobretudo do desobediente civil, que busca o aperfeiçoamento da vida política do Estado e atua em conformidade com os princípios que informam a república, ou seja, apenas exerce o direito de resistir ao direito.

Sobre essa polêmica, Freemam pretendendo demonstrar a iniquidade dessa pretensa característica afirma que: "nenhum advogado diz no tribunal: Meritíssimo, este homem deseja ser punido". ${ }^{20}$ Por outro lado, procurando ponderar a questão, Dworkin aduz que: "se um ato de desobediência civil pode alcançar seu objetivo sem punição, isso geralmente é melhor para todos os envolvidos". ${ }^{21}$

Assim, entendemos que não se pode estabelecer um requisito que poderia significar, em muitos casos, relegar à marginalidade o desobediente civil, tratando-o do mesmo modo que se trata um criminoso ou outro agente pernicioso ao bom funcionamento da sociedade. De tal forma, busca-se construir uma teoria capaz de integrar a teoria da desobediência civil com a seara penal, a fim de que a legitimidade do ato contestador também ecoe no aparato repressivo da sociedade.

\section{A RESPEITO DA CULPABILIDADE NA SEARA PENAL}

Conceituado por Nilo Batista ${ }^{22}$ como: "o conjunto de normas jurídicas que prevêem os crimes e lhes cominam sanções, bem como disciplinam a incidência e validade de tais normas, a estrutura geral do crime, e a aplicação e execução das sanções cominadas", o direito penal pode ser compreendido como o instrumento pelo qual o Estado efetiva o controle social, proibindo a prática de determinadas condutas.

Segundo os ensinamentos do filósofo Michel Foucault ${ }^{23}$, a repressão penal estatal superou a fase dos suplícios, em que os condenados eram humilhados, torturados, degolados, esquartejados, queimados em praça pública, nos brutais espetáculos de demonstração do poder do soberano, para alcançar a racionalidade

\footnotetext{
${ }^{20}$ Apud ARENDT, Hannah. op. cit. p. 54.

${ }^{21}$ DWORKIN, Ronald Myles. Uma questão de princípio. 2. ed. São Paulo: Martins Fontes, 2005.p. 170.

${ }^{22}$ BATISTA, Nilo. Introdução Crítica ao Direito Penal brasileiro. Rio de Janeiro: Revan, 2007. p. 24.

${ }^{23}$ cf. FOUCAULT, Michel. Vigiar e punir: nascimento da prisão. 20. ed. Petrópolis: Vozes, 1999. passim.
} 
das prisões, em que apenas a liberdade do infrator é suprimida, no processo de adestração e "docilização dos corpos". Portanto, as prisões e toda a processualística penal contemporânea estariam de acordo com a nova concepção do poder, em que a vingança do soberano dá lugar à defesa da sociedade burguesa.

Dentro desta ótica, podemos afirmar que o controle social exercido pelo Estado por meio do aparato criminal está em constante evolução, buscando adequar-se às peculiaridades da vida moderna, moldando-se às relações de poder da sociedade. A denominação culpado, nos dias atuais, é muito diferente daquela atribuída aos infratores da lei de antigamente.

É do célebre jurista alemão, Franz von Liszt, a afirmaçãode que: "pelo aperfeiçoamento da teoria da culpabilidade mede-se o progresso do Direito Penal" ${ }^{24}$ De tal forma, exsurge a necessidade da criteriosa investigação da noção de culpabilidade que influencia o direito penal brasileiro.

Nesse sentido, importante ressaltar que o Código Penal jamais conceituou a culpabilidade, encarregando esta tarefa à doutrina. Fruto de grandes debates, a evolução doutrinária do conceito e características da culpabilidade passou pelas teorias psicológica, normativa, normativa pura até chegar à teoria limitada. ${ }^{25}$

Congregando os preceitos da teoria normativa pura, a teoria limitada conserva os elementos psicológicos (dolo e culpa) no interior da conduta, de modo que a culpabilidade passa a ser o juízo de censura que recaí sobre o autor do fato típico e antijurídico.

Não obstante, a culpabilidade também integra outra discussão ferrenha no universo jurídico: o seu lugar na teoria do crime. Isso se dá pelo fato de parte da doutrina entender o crime como a conjugação de "fato típico e ilícito", concebendo a culpabilidade como "mero pressuposto de aplicação da pena". Em contrapartida, apoiando-se na maioria da doutrina brasileira ${ }^{26}$, entendemos que a culpabilidade seria um elemento constitutivo do crime, ou seja, o delito seria o resultado de um fato típico, ilícito e culpável.

A culpabilidade, nesse estudo, ganha relevo em razão de ser o elemento fundamental para operacionalizar a integração da desobediência civil com a

\footnotetext{
${ }^{24}$ Apud BUSATO, Paulo César. Direito Penal: Parte geral. São Paulo: Atlas, 2013. p. 523.

${ }^{25} \mathrm{O}$ item 19 da exposição de motivos da nova parte geral do Código Penal, de 1984, deixa bem claro que a teoria adotada pelo ordenamento pátrio é a limitada.

${ }^{26}$ Partilham desta visão na doutrina brasileira, entre outros: Basileu Garcia; José Frederico Marques; Edgard Magalhães Noronha; João Mestiéri; Fernando Galvão; Cezar Roberto Bittencourt; Rogério Greco; Paulo Queiroz e Paulo Cesar Busato.
} 
dogmática penal, a fim de verificar o juízo de censura que recai sobre aqueles que ousam resistir e lutar contra os desmandos do Estado, desobedecendo normas ou atos de autoridades públicas.

Para verificar o grau de reprovabilidade do contestador civil, torna-se necessária uma breve análise dos elementos constitutivos da culpabilidade que, de acordo com a análise do Código Penal, seriam: imputabilidade, potencial consciência da ilicitude e exigibilidade de conduta de diversa.

A imputabilidade pode ser entendida como a capacidade do agente que cometeu o fato típico e ilícito em compreender o comando normativo da norma jurídica. Abarcaria em seu bojo o aspecto intelectivo, que seria a capacidade de entendimento do ato, e o volitivo, que pode ser entendido como a capacidade de controlar suas próprias ações. Assim, definiu o Código Penal quem seriam os inimputáveis, a saber: os doentes mentais, aqueles que possuam desenvolvimento mental incompleto, aqueles que possuam desenvolvimento mental retardado e aquelas pessoas em caso de embriaguez acidental completa.

Não obstante, outro elemento que compõe o conceito de culpabilidade é a potencial consciência da ilicitude que pode ser entendida como o conhecimento pelo agente da prática de uma conduta contrária ao direito. Ainda que o desconhecimento da lei não exima o agente da sanção penal (art. $3^{\circ}$ da LINDB e 21 do Código Penal), se provado que o agente não tinha condições de saber a ilicitude da conduta praticada sua ação não pode ser punida ou, em alguns casos, a punição deve ser minorada.

A exigibilidade de conduta diversa - elemento mais importante para realizar a integração da teoria da desobediência civil com o campo penal - consiste no juízo de valor da sociedade sobre a prática do fato típico e ilícito, em que se vindica uma ação diferente (em conformidade com a norma) daquela assumida pelo agente infrator, uma vez que ele poderia deliberar livremente sobre sua prática. Todavia, caso seja inexigivel uma conduta diversa por parte do infrator, uma vez que apenas comportamentos que podem ser evitados é que merecem ser punidos, excluir-se-á a culpabilidade e, consequentemente, o crime.

Fundamenta-se o aludido instituto na concepção de que o direito não pode exigir do cidadão atos heroicos. Há de se aferir no caso concreto a possibilidade de o agente atuar conforme o direito, a partir da compreensão jurídica que possui.

De tal forma, conclui-se que somente recairá um juízo de reprovação sobre aquele agente que tinha a possibilidade de agir de modo diverso. Imperioso destacar, 
inclusive, que este é o entendimento do C. Superior Tribunal de Justiça, para o qual: "a exigibilidade de conduta diversa, apesar de apresentar muita polêmica, é, no entendimento predominante, elemento da culpabilidade". Ademais, como enfatiza o próprio tribunal "por via de conseqüência, sem adentrar na questão dos seus limites, a tese da inexigibilidade de conduta diversa pode ser apresentada como causa de exclusão da culpabilidade". ${ }^{27}$

O Código Penal consagrou em seu artigo 22 os institutos da coação moral irresistível e da obediência hierárquica, como causas legais de exclusão da culpabilidade em razão da inexigibilidade de conduta diversa, podendo-se falar ainda no excesso na prática da legítima defesa.

Todavia, a doutrina e a jurisprudência vêm construindo outros casos de exclusão da culpabilidade por inexigibilidade de conduta diversa, a saber: 1) consentimento do ofendido; 2) objeção de consciência (com fulcro no art. $5^{\circ}$, VI, CRFB); 3) provocação da situação de legítima defesa; 4) excesso decorrente da legítima defesa; 5) estado de necessidade exculpante; 6) conflito de deveres; e 7) desobediência civil.

\section{DESOBEDIÊNCIA CIVIL COMO CAUSA DE EXCLUSÃO DA CULPABILIDADE: A (IN)EXIGIBILIDADE DE CONDUTA DIVERSA}

Em princípio, insta lembrar que a desobediência civil atua para ampliar a própria ideia de democracia, por meio de protestos, baseando-se nos próprios princípios e fundamentos da república. Por outro lado, a desobediência comum (ou criminal) busca satisfazer interesses egoísticos próprios, bem como expressar sua raiva, sua vingança, sua crueldade, ou até mesmo a sua dose de perversidade, elementos evidentemente incompatíveis com os preceitos da vida equilibrada em sociedade.

De tal forma, ações de desobediência civil não podem ser tratadas de forma semelhante às ações criminosas - aliás, vale destacar que nem todo ato de desobediência civil repercute na esfera criminal, mas apenas alguns, em determinadas e específicas ocasiões. É preciso compreender, por outro lado, que a desobediência

\footnotetext{
${ }^{27}$ BRASIL. Superior Tribunal de Justiça.5a Turma. HC 16.865/PE. Rel. Min. Felix Fisher. j. 09.10.2001. Disponível em:<http://stj.jusbrasil.com.br/jurisprudencia/299208/habeas-corpus-hc-16865-pe-2001-0060677-2>. Acesso em: 19 set. 2015.
} 
civil está albergada pelo ordenamento jurídico brasileiro e é utilizada para pressionar os detentores do poder.

Nesse sentido, o Ilmo. Gilmar Mendes, ministro da mais alta corte do nosso país, valendo-se dos ensinamentos do mestre português, Canotilho, já sentenciou que a desobediência civil está albergada pelo Estado democrático de Direito brasileiro e não pode ser confundida com a criminalidade comum, in verbis:

Não é possível qualificar como crime de quadrilha eventuais manifestações coletivas de desagravo ou de desobediência civil, sob pena de inversão dos valores do Estado de democrático, com inequívoco reflexo no direito de manifestação e de reunião, constitucionalmente assegurados (art. $5^{\circ}$, IV e XVI).

É claro que não estou a defender a desordem e, por via de consequência, admitir que, em nome da liberdade de manifestação ou de reunião, é possível praticar crimes diversos. Friso, o que estou a afirmar é que as manifestações individuais ou coletivas, por si sós, evidentemente, não são ilícitas.

A propósito, leciona Canotilho que, "sob o ponto de vista jurídico constitucional, a desobediência civil poder-se-ia caracterizar como o direito de qualquer cidadão, individual ou coletivamente, de forma pública e não violenta, com fundamento em imperativos ético-políticos, poder realizar os pressupostos de uma norma de proibição, com a finalidade de protestar, de forma adequada e proporcional, contra uma grave injustiça (Dreier). Trata-se, assim, de dar guarida constitucional ao "direito à indignação", procurando-se convencer a opinião pública de que uma lei, uma política ou medidas de uma política são ilegítimas tornando-se a contestação pública destas plenamente justificada"28 (grifo nosso).

É a partir do reconhecimento da desobediência civil como um direito-dever que poderemos afastar os olhares desconfiados que repousam sobre os desobedientes civis, além de avançarmos rumo a uma dogmática penal que reconheça a necessidade da discussão acerca da legitimidade e a legalidade do ato desobediente e da própria lei, abandonando-se a concepção tecnocrata que apenas reduz o direito à lei, que infelizmente predomina na seara criminal.

A análise apurada dos elementos que compõem a culpabilidade, mais precisamente sobre a exigibilidade de conduta diversa, pode representar uma luz ao sombrio horizonte da dogmática penal brasileira, possibilitando a sua

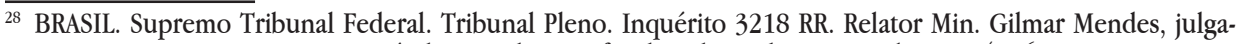
mento em 21 mar. 2013. Disponível em: <http://stf.jusbrasil.com.br/jurisprudencia/24806872/inquerito-inq3218-rr-stf/inteiro-teor-112280472>. Acesso em: 19 set. 2015. 
harmonização aos princípios que regem a Constituição Federal. Dentro desta ótica, a desobediência civil pode ser considerada uma dirimente da culpabilidade pelo fato de o cidadão não ter outro modo de agir, senão desobedecendo a norma, isto é: torna-se inexigivel um comportamento socialmente diverso por parte do agente desobediente.

$\mathrm{Na}$ esteira desse pensamento, Juarez Cirino dos Santos argumenta que a desobediência civil poderia ser entendida como situação de exculpação extralegal, decorrente justamente da inexigibilidade de conduta diversa, in verbis:

Autores de fatos qualificados como desobediência civil são possuidores de dirigibilidade normativa e, portanto, capazes de agir conforme ao direito, mas a exculpação se baseia na existência objetiva de injusto mínimo, e na existência subjetiva de motivação pública ou coletiva relevante, ou, alternativamente, na desnecessidade de punição, porque os autores não são criminosos - portanto, a pena não pode ser retributiva e, além disso, a solução de conflitos sociais não pode ser obtida pelas funções de prevenção especial e geral atribuídas à pena criminal $^{29}$ (grifos do autor).

O entendimento que aqui se constrói coaduna-se com os preceitos que regem a seara penal, contribuindo para o seu aperfeiçoamento e integração a outras áreas do direto, além dos princípios que dão o suporte para a seara penal, como o da intervenção mínima. A compreensão da desobediência civil como um ato de protesto inerente ao jogo democrático, além de trazer uma série de benefícios para a própria sociedade, afastaria a caracterização do delito (teoria finalista tripartida) ou seria óbice à aplicação da pena (teoria finalista bipartida).

O reconhecimento da desobediência civil no campo criminal, contudo, depende da observância de algumas condições, a fim de que não se instale a balburdia, a saber: o ato ilícito tenha sido praticado em defesa das prerrogativas inerentes à cidadania e que busque a proteção de direitos fundamentais.

Conforme destaca Claus Roxin ${ }^{30}$, a desobediência civil pode ser considerada uma causa de exculpação supralegal, desde que atendidos determinados requisitos, pois o desrespeito à lei é juridicamente irrelevante, por estar diretamente ligado ao direito fundamental de manifestação no Estado democrático de Direito, e pela motivação do agente - elemento relevante para a culpabilidade - estar guiada pelo

\footnotetext{
${ }^{29}$ SANTOS, Juarez Cirino dos. Direito Penal: parte geral. 3. ed. Curitiba: Lumen Juris, 2008. p. 345

${ }^{30}$ ROXIN, Claus. Derecho Penal: Parte General. Tomo I. Fundamentos. La estructura de la teoría del delito. Madri: Civitas, 1997. p. 953-955.
} 
bem comum, o que acarreta a reprovabilidade muito pequena, não carecendo da atuação do aparelho repressivo do Estado. Além disso, o célebre penalista alemão ressalta que a punição aos desobedientes civis pode inflamar ainda mais a revolta, potencializando o cometimento de delitos mais graves, e em nada contribui para a "prevenção geral" do direito penal.

Não se pode negar, evidentemente, que o bem jurídico eventualmente violado por um ato de desobediência civil mereça consideração e, ainda, que o direito penal deva agir para coibir eventuais abusos dos contestadores civis. O que se torna necessário é que esta consideração e proteção atuem de forma conjunta com o direito-dever de desobedecer a uma norma injusta. O objetivo norteador do direito penal é e sempre será a pacificação social, e a desobediência civil contribui para isso, ainda que em longo prazo.

Sobre o tema, Dieter ${ }^{31}$, buscando a adequação constitucional do direito penal, afirma que: "a desobediência civil constitui em regra uma situação supralegal de exculpação de fundamento constitucional, porque o exercício do direito fundamental de resistir ou protestar é condição de existência do Estado democrático de Direito", aduzindo também que a prática desobediente "demanda especial proteção para impedir a possibilidade de criminalização de legítimas manifestações diretas do soberano poder popular".

De tal forma, verifica-se que a legitimidade da desobediência civil irradia seus efeitos para as mais variadas áreas do direito, de modo a inviabilizar-se, no campo penal, a criminalização do agente desobediente. Afinal, não se pode dele exigir outra medida que não seja lutar contra a opressão que lhe cerca, ou seja, é inexigível conduta diversa por parte do cidadão. O exemplo de Rosa Parks demonstra que o cidadão, em casos de opressão extrema, é praticamente compelido a desobedecer à norma jurídica e não merece, portanto, ser submetido ao calvário do cárcere.

Tendo o direito penal assumido o compromisso de resguardar os bens jurídicos mais relevantes para a sociedade, deverá este promover e proporcionar a integridade física e moral dos desobedientes civis que empenham seus esforços como um verdadeiro mecanismo de defesa e resistência contra as arbitrariedades e negligências perpetuadas pelos reais detentores do poder. Resguardar a legitimidade

\footnotetext{
${ }^{31}$ DIETER, Maurício Stegemann. A inexigibilidade de comportamento adequado à norma penal e as situações supralegais de exculpação. 20 de maio de 2008. 192 p. Dissertação (Mestrado em Direito). Faculdade de Direito da Universidade Federal do Paraná, Curitiba, 2008. Disponível em: < http:/hdl.handle.net/1884/15149>. Acesso em: 20 jun. 2016. p. 140.
} 
da desobediência civil e impedir o exercício do jus puniendi estatal é possibilitar que os cidadãos e movimentos sociais continuem a tensionar o debate público, viabilizando a radicalização da democracia. Deve-se, portanto, garantir o seu exercício, afastando-se a criminalização dos cidadãos, ante a ausência de reprovabilidade social da conduta.

\section{CONCLUSÃO}

A concepção de um ordenamento jurídico fechado em si mesmo e alheio aos anseios da população é diariamente rejeitada pelos cidadãos brasileiros. A edificação da participação popular no centro das decisões políticas é o desafio a ser superado por todos aqueles que buscam a construção de uma sociedade livre, justa e solidária.

Verifica-se que a efetivação da cidadania, expressão política da liberdade, exige medidas inovadoras e corajosas. A desobediência civil deve ser compreendida dentro desta ótica que busca o aperfeiçoamento da sociedade política, pois tem o condão de alterar as estruturas do Estado, por meio da pressão popular. A ação desobediente apresenta-se, assim, como fenômeno capaz de gerar o imprescindível diálogo entre o poder público e os cidadãos, quando todos os outros canais de comunicação estiverem interrompidos.

Embora notáveis desobedientes civis e de igual modo, boa parte da doutrina assinala a aceitação voluntária das sanções como uma característica indispensável da desobediência civil, as dores e o calvário do cárcere parecem demasiadamente danosas aos desobedientes civis. Afirmar que o contestador civil deve submeter-se à prisão de bom grado, apenas por manifestar um direito, não parece razoável.

Nesse sentido, o presente trabalho intentou investigar a desobediência civil como causa supralegal de exclusão da culpabilidade, para afastar a eventual responsabilidade penal do agente desobediente, a fim de assegurar o exercício da prática contestadora, desde que esteja em harmonia com os princípios informadores da república e respeite direitos fundamentais. A pecha de criminoso ou de mau elemento, dentro desta ótica, não deve ser atribuída ao desobediente civil que agir guiado pelos preceitos constitucionais e pelos mais altos valores da justiça.

A moderna teoria acerca da culpabilidade, não obstante, representa a evolução empreendida pela sociedade para determinar o juizo de censura ou de 
reprovabilidadedo agente responsável pelo cometimento do fato típico e do ato ilícito/antijurídico. A reprovação jurídico-penal, portanto, envolve a análise pessoal do agente diante das circunstâncias que o motivaram a agir em desacordo com o preceito penal.

Dentro desse contexto, ganham relevo as causas legais e supralegais de exclusão da culpabilidade, que se subdividem em imputabilidade, potencial consciência da ilicitude e exigibilidade de conduta diversa. Como demonstrado ao longo da pesquisa, a exigibilidade de conduta diversa é o elemento capaz de realizar a integração da desobediência civil com a seara penal, pois eleva a discussão a respeito da infração penal cometida pelo agente ao plano ético-social.

Importa ressaltar que, apesar de gerar bastante polêmica no universo jurídico, a exigibilidade de conduta diversa é elemento da culpabilidade e deve ser compreendida em toda sua magnitude, a fim de impedir a configuração do delito (teoria finalista tripartida) ou obstar a aplicação da pena (teoria finalista bipartida), caso não seja possível exigir uma conduta diversa por parte do agente. A sociedade somente pode reprimir penalmente uma conduta quando seja razoável vindicar uma conduta diferente por parte do agente desobediente.

A compreensão de que a desobediência civil é o último recurso que dispõe o cidadão, não obstante, facilita a compreensão de que não é minimamente justo exigir ou reivindicar outra ação do cidadão que recorrer à desobediência como forma de pressionar o poder público. A legitimidade da desobediência civil, desde que respeite os direitos humanos, deve repercutir também na seara penal, a fim de impedir as aflições do cárcere aos contestadores civis.

Infere-se com o trabalho realizado, portanto, que a desobediência civil enquadra-se como uma causa supralegal de exclusão da culpabilidade, em razão de ser inexigível do desobediente civil uma conduta diversa da praticada, pois este apenas exerce um direito-dever de lutar contra a opressão travestida de legalidade, apoiando-se nos princípios da cidadania e da soberania popular. Luta-se, de tal forma, em defesa dos preceitos democráticos.

\section{REFERÊNCIAS}

ARENDT, Hannah. Crises da república. São Paulo: Perspectiva, 1973.

BATISTA, Nilo. Introdução Crítica ao Direito Penal Brasileiro. Rio de Janeiro: Revan, 2007. 
BARRETO, Luciana Augusto. FARIAS, Paloma Leite Diniz. Desobediência Civil enquanto causa supralegal de exclusão de culpabilidade. Disponível em:<revista.uepb.edu.br/index.php/datavenia/article/download/510/293>. Acesso em 12 jan. 2015.

BOBBIO, Norberto; MATTEUCCI, Nicola; PASQUINO, Gianfranco. Dicionário de política. 10. ed. Brasília: UNB, 1997. v1.

BRASIL. Supremo Tribunal Federal. Tribunal Pleno. Inquérito 3218 RR Relator Min. Gilmar Mendes, julgamento em 21 mar. 2013. Disponível em: < http:// stf.jusbrasil.com.br/jurisprudencia/24806872/inquerito-inq-3218-rr-stf/inteiroteor-112280472>. Acesso em 19 set. 2015

BRASIL. Superior Tribunal de Justiça. $5^{\text {a }}$ Turma. HC 16.865/PE. Rel. Min. Felix Fisher. j.09.10.2001. Disponível em:<http://stj.jusbrasil.com.br/jurisprudencia/299208/ habeas-corpus-hc-16865-pe-2001-0060677-2> . Acesso em: 19 set. 2015.

BUSATO, Paulo César. Direito Penal: Parte geral. São Paulo: Atlas, 2013.

BUZANELlO, José Carlos. Direito de Resistência Constitucional.2. ed. Rio de Janeiro: Lumem Juris, 2006.

COELHO, Roberta Werlang. Direito de Resistência e Desobediência Civil:Causas Supralegais de Exclusão da Infração Penal. Disponível em: < http://www3.pucrs.br/ pucrs/files/uni/poa/direito/graduacao/tcc/tcc2/trabalhos2007_2/Roberta_Werlang. pdf $>$. Acesso em: 12 jan. 2015.

COSTA, Nelson Nery. Teoria e realidade da desobediência civil. Rio de Janeiro: Forense, 2000.

DECLARAÇÃO DOS DIREITOS DO HOMEM E DO CIDADÃO DE 1789. Disponível em: <http://www.fafich.ufmg.br/hist_discip_grad/DeclaraDireitos.pdf $>$. Acesso em: 22 jun. 2016.

DIETER, Maurício Stegemann. A inexigibilidade de comportamento adequado à norma penal e as situações supralegais de exculpação. 2008. 192f. Dissertação (Mestrado em Direito) - Faculdade de Direito daUniversidade Federal do Paraná, 
Curitiba, 2008. Disponível em:<http:/hdl.handle.net/1884/15149>. Acesso em: 20 jun. 2016.

DWORKIN, Ronald. Uma questão de princípio. 2. ed. São Paulo: Martins Fontes, 2005.

FOUCAULT, Michel. Vigiar e punir: nascimento da prisão. 20. ed. Petrópolis: Vozes, 1999.

GARCIA, Maria. Desobediência Civil: direito Fundamental. 2. ed. São Paulo: Revista dos Tribunais, 2004.

HABERMAS, Jürgen. Direito e democracia: entre facticidade e validade. Rio de Janeiro: Tempo Brasileiro. 1997. v2.

HOBBES, Thomas. Leviatã: ou matéria, forma e poder de uma república eclesiástica e civil. São Paulo, Mandamentos, 2003.

LEHFELD, Lucas de Souza. Modalidades de Participação-Cidadã no Horizonte de Concreção do Direito. In. FERREIRA, Luiz Alexandre Cruz (Org.). Hermenêutica, Cidadania e Direito. Campinas: Millennium, 2005. p. 159-187.

PAUPÉRIO, Arthur Machado. O Direito político de resistência. Rio de Janeiro, Forense: 1978.

PRANDO, Felipe Cardoso. Desobediência civil: uma possibilidade para a realização dos Direitos Humanos. 2012. 130f. Dissertação (Mestrado em Direito) - Universidade Federal de Santa Catarina. Florianópolis, 2012. Disponível em: < https://repositorio. ufsc.br/handle/123456789/83869>. Acesso em: 05 jun. 2015.

RAWLS, John. Uma teoria da justiça. Lisboa: Fundamentos, 1993.

REPOLÊS, María Fernanda Salcedo. Habermas e a desobediência civil. Belo Horizonte: Mandamentos, 2003.

RIBEIRO, Fernando Aramando. Conflitos no Estado Constitucional Democrático: por uma compreensão jurídica da desobediência civil. Belo Horizonte, Mandamentos, 2004. 
ROXIN, Claus. Derecho Penal: Parte General. Tomo I. Fundamentos. La estructura de la teoría del delito.Madri: Civitas, 1997

SANTOS, Juarez Cirino dos. Direito Penal: parte geral. 3. ed. Curitiba: Lumen Juris, 2008.

TAVARES, Geovani de Oliveira. Desobediência civil e direito político de resistência. Campinas: Edicamp, 2003.

TEOTÔNIO, Paulo José Freire. Normas jurídicas inconstitucionais. Leme: AM, 2011.

THOREAU, Henry David. A desobediência civil.Porto Alegre: L\&PM, 2011.

Recebido em: 10 de agosto de 2016 Aceito em: 19 de junbo de 2016 